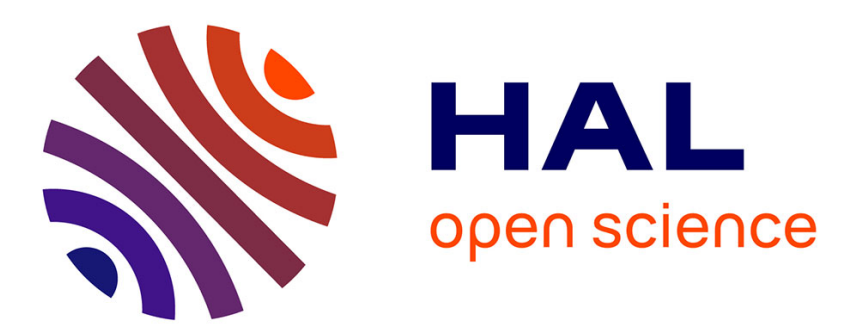

\title{
Early phase drugs and biologicals clinical trials on worldwide leading causes of death: a descriptive analysis Rafael Dal-Ré
}

\section{To cite this version:}

Rafael Dal-Ré. Early phase drugs and biologicals clinical trials on worldwide leading causes of death: a descriptive analysis. European Journal of Clinical Pharmacology, 2011, 67 (6), pp.563-571. 10.1007/s00228-011-1036-1 . hal-00685387

\section{HAL Id: hal-00685387 https://hal.science/hal-00685387}

Submitted on 5 Apr 2012

HAL is a multi-disciplinary open access archive for the deposit and dissemination of scientific research documents, whether they are published or not. The documents may come from teaching and research institutions in France or abroad, or from public or private research centers.
L'archive ouverte pluridisciplinaire HAL, est destinée au dépôt et à la diffusion de documents scientifiques de niveau recherche, publiés ou non, émanant des établissements d'enseignement et de recherche français ou étrangers, des laboratoires publics ou privés. 


\section{Early -phase drugs and biologicals clinical trials on}

worldwide leading causes of death: a descriptive analysis

Rafael Dal-Ré MD, PhD, MPH

Department of Preventive Medicine, Public Health and Medical Immunology and Microbiology, School of Health Sciences, Rey Juan Carlos University, Alcorcón, Madrid, Spain

Address: Dr R Dal-Ré; Departamento de Medicina Preventiva y Salud Pública e Inmunología y Microbiología Médicas, Facultad de Ciencias de la Salud, Universidad Rey Juan Carlos, Avda Atenas s/n; 28922 Alcorcón, Madrid, España. Phone: +34-91-488 8804;

Fax: +34-91-488 8955 .

Email: rafael.dalre@urjc.es 


\section{Purpose}

To describe the global effort on currently "open" early-phase clinical trials with medicines on the major causes of mortality.

\section{Methods}

16 of the 20 leading causes of death were chosen; 9 of these were also amongst the top ten causes of death in low-income countries. Studies were identified from the Clinicaltrials.gov database to include phase 1 and/or 2 "Interventional"“"open" trials-i.e. recruiting or about to start recruitment-by Sponsorship -Industry, Universities and other organisations (UNO), and US Federal Agencies (NIH included)-,by gender and age groups, conducted with drugs and/or biologicals. The search was performed on March 2010

Results

2298 (824 phase $1 ; 1474$ phase 2 ) trials were retrieved. $67 \%$ of all were on trachea, bronchus and lung cancers (25\%), diabetes mellitus(15\%), colon and rectum cancers (14\%) and HIV/AIDS (12\%). On the contrary, $4 \%$ were trials on diarrhoeal disease, nephrosis and nephritis, liver cirrhosis, and prematurity and low birth weight. UNO were the first source of funding. $52 \%$ of phase 1 non-cancer trials were on healthy volunteers. $29 \%$ of all trials were co-funded. Trials with drugs accounted for 4.6 times as much as those with biologicals. Only $7 \%$ were conducted with drugs and biologicals, the majority $(78 \%)$ on cancers. No discrimination neither by gender nor by age group was observed. 


\section{Conclusions}

More than 2/3 of early-phase trials were in 4 of the 16 diseases considered. Cancers were a top priority for all sponsors. Increasing attention should be given to conditions with current and projected global high mortality rates that had few "open" early phase trials.

Keywords: Clinicaltrials.gov; drugs and biologicals; healthy volunteers; phase 1 and 2 clinical trials; worldwide mortality. 
In September 2004 the International Committee of Medical Journal Editors (ICMJE) published a new policy, to become effective in 2005, requiring investigators to register information about their trials in an accepted clinical trials registry before starting patient enrolment [1]. Soon after, under the World Health Organization (WHO) leadership, a multidisciplinary team agreed the minimum data set about design, conduct and administration of a study to be disclosed. Contrary to the initial ICMJE's proposal, it was decided that all trials -including phase 1- must be registered before study start [24]. Data showed that the ICMJE policy dramatically impacted the number of trials registered on the largest registry, Clinicaltrials.gov (CTG) [5]. Thus, one month after the policy went into effect, the number of registered trials jumped from $>13000$ to close to 23000 [6]. In March 2010, close to 88000 studies were registered in CTG. The increasing registration of trials before starting recruiting subjects in CTG [5] and the publication of the WHO comprehensive report about the leading causes of death [7], made it possible to analyse what was the global effort on early-phase trials devoted to investigate new medicines or new approaches with drugs or biologicals to combat the major causes of mortality on a worldwide basis.

\section{Methods}

This analysis was conducted using Clinicaltrials.gov registered studies as of March $24^{\text {th }}$, 2010. A careful assessment on the impact of the search fields in order to provide the optimal inclusion of the data for review was carried out. To fulfil the study objective, it was preferred to use the "open" (i.e. "recruiting", "not yet recruiting") rather than the “closed" (i.e. "active, but not recruiting") descriptor, and although studies that were "active, but not recruiting" anymore may be lost, it would avoid the inclusion of studies 
that have been "terminated" or "completed" some years back. So, the fields chosen were "study type: interventional", "recruitment: open"; "study results: all”; "conditions"; "interventions: drugs and/or biologicals"; "Gender"; "Age group"; "phase:1 and/or 2"; “funded: University/Organization (UNO), Industry (INY) and National Institutes of Health and Other US Federal Agency” (FED) merged together (Appendix A). In addition, "healthy volunteers" was used as a specific "search term". Although CTG has a validation system in place [9], it relies ultimately on the accuracy of the data introduced by thousands of scientists, this being a source of inconsistencies and errors when filling-in the CTG fields. A review of inconsistencies was conducted when reviewing the data retrieved from CTG.

Sixteen of the 202004 leading causes of death, accounting for $58 \%$ of all worldwide mortality, were included in the analysis [7]. Since WHO and CTG may name diseases or conditions differently, among CTG's "conditions" the one that could best match each of the WHO's causes of death was chosen, using ICD10 as guidance [8] (table 1). However, with ischaemic heart disease, hypertensive heart disease and cerebrovascular disease, more than one "condition" was chosen in order to capture the majority of studies (table 1). On the other hand, WHO's diarrhoeal diseases is more restrictive that CTG's diarrhoea; hence, the search was done excluding traveller diarrhoea, antibioticassociated, chemotherapy-induced, radiation, irritable bowel disease, IBS and cancer.

Among the 20 conditions, four were not included in this analysis: three are not suitable for experimental clinical research ("road traffic conditions", "self-inflicted injuries" and "birth asphyxia and birth trauma"), whereas the fourth one ("neonatal infections") had a complex definition -a category that following the WHO description also includes 'other 
non-infectious causes arising in the perinatal period, that are responsible for $20 \%$ of deaths in this category' [7], that makes it impossible to match it with CTG conditions.

\section{Results}

In 200471 “open”, “interventional”, phase 1, studies with drugs and/or biologicals were registered on CTG, 14 on them on the 16 conditions considered; these figures were 150 and 17 for phase 2 trials, respectively. In 2010, the total "open", "interventional" phase 1 trials and those related to the 16 conditions have climbed to 4145 and 824 , respectively; these figures were 6552 and 1474 for phase 2 trials, respectively (table 2). US centres were involved on the $56 \%$ of all phase 1 and/or 2 trials on the diseases considered.

Specific data on the number of both phase 1 or 2 trials, with regards to the 16 conditions, sponsorship, gender and age-groups accepted for inclusion are shown in tables 2-4. Sixty seven percent of all phases 1 and/or 2 trials were on trachea, bronchus and lung cancers $(25 \%, 574 / 2298)$, diabetes mellitus (15\%, 346/2298), colon and rectum cancers $(14 \%, 333 / 2298)$ and HIV/AIDS $(12 \%, 283 / 2298)$ (table 2). On the contrary, $4 \%$ were trials on diarrhoeal disease, nephrosis and nephritis, liver cirrhosis, and prematurity and low birth weight. Malaria was the only condition with more phase 1 than phase 2 trials. Trials with drugs accounted for 4.6 times as much as those with biologicals. Seven percent (161/2298) were conducted with drugs and biologicals, the majority $(78 \%, 126 / 161)$ on cancers (table 2). Fifty two percent of phase 1 (non-cancer) trials were conducted on healthy volunteers; $36 \%$ of phase 1 trials, were labelled as phase 1 and 2 trials (table 2). UNO were the first source of funding $(60 \%, 1378 / 2298)$, co-funding 46\% (627/1378) of their sponsored trials. Twenty nine percent (674/2298) of all were co-funded trials (table 3). 
Twelve percent (270/2298) of phase 1 and/or 2 trials accepted $\leq 17$-year old subjects.

Respiratory tract infections, diabetes and HIV/AIDS accounted for 54\% in both phase 1 (52/97) and 2 (93/173) trials accepting minors (table 4). Seniors were included in almost all diseases except on prematurity and low birth weight trials. Females and males were accepted for inclusion in both phase 1 and 2 trials in a balanced manner in all conditions (table 4).

\section{Discussion}

This study provides a snapshot of "open" early-phase clinical research conducted with drugs and/or biologicals in 16 of the 202004 worldwide major causes of death as of March 2010.

The most striking finding observed was not the fact that cancers (mainly trachea, bronchus and lung and colon and rectum neoplasms) were leading the interest of all sponsors, but the high percentage of effort devoted to them. Except HIV/AIDS and diabetes mellitus, which were highly interested single conditions for FED and INY, respectively, $45 \%$ trials were on cancers. Hence, the global effort on early cancer development trials is really remarkable. There were many medicines (and new combination regimens) in early-phase trials that hopefully will help future patients in high- and middle-income countries in which both trachea, bronchus and lung and stomach cancers are predicted to be among the 10 leading causes of mortality in 2030 [10]. Of note is also the number of biologicals on early clinical development, expanding the approaches to the treatment of cancer patients. To this end, modern technology (e.g. cancer genomics and proteomics, circulating tumour cells) and the use of validated biomarkers are key to increase the success of cancer treatment [11]. 
On the other hand, there were a number of diseases with almost no interest to public and private sponsors. These included conditions not only prevalent in developing countries (e.g. diarrhoea, prematurity and low birth weight) but also in developed societies (e.g. COPD). It's obvious that prevention and treatment of these conditions should mainly rely on changes on individual behavioural (e.g. smoking, diet, alcohol intake, physical activity) and community (e.g. water supply, sanitation) changes and this could explain, to some extent, the scarce number of trials initiated with drugs and biologicals.

Data suggests that overall participation of women and men in trials supporting the marketing authorization of new medicines in Europe [12] and the US [13] is comparable. However, significant under-representation of women in early-phase trials has been also observed - Fleish et al showed an overall proportion of only $37 \%$ of female participants in phase 1 and 2 trials results published in 2001 in three major Clinical Pharmacology journals [14]. Furthermore, more recent data showed that among 352 phase 1 trials of 30 new molecular entities submitted to the US Food and Drug Administration (FDA) in 2006-2007 for non-sex specific indications, only $31 \%$ of participants were women and that $34 \%$ of trials had only men volunteers [15]. This analysis shows that there was not a gender bias with regards to early-phase clinical trials selection criteria. This being required, is not enough to ensure women are appropriately represented: female participants should be actively invited to participate in these early phase trials. With this respect, Pinnow et al [15] data are encouraging: the number of trials that enrolled women and the number of women participating in phase 1 has increased over time since 2001, albeit women are still under-represented. Finally, it should be highlighted that this analysis shows no gender discrimination in both healthy volunteers and patient trials, the first step to prevent what was previously observed [14], 
i.e. to have higher proportion of women participating in patient trials than in healthy volunteers ones .

This analysis shows that elderly people were not excluded from most of early development trials. In a 2005 editorial, McMurdo et al [16] shared their concerns regarding the evidences of having older people excluded from clinical trials. This is more relevant for cancer trials than for the other conditions considered in this study, since volunteers in oncology trials have to be patients from the very beginning of clinical research. Trials submitted to the FDA supporting new cancer therapies [17] showed that elderly was under-represented for all cancer treatment except for breast cancer hormonal therapies, despite the fact that seniors are willing to consider participation in cancer trials [18]. This analysis shows that elderly people could participate in $99 \%$ of phase 1 and/or 2 cancer trials. However, what really matters is to actually have enough seniors participating in these trials, to better design phase 3 studies for this patient population.

Minors were accepted in only $12 \%$ of all phase 1 and/or 2 trials on drugs and biologicals. This figure could seemed low considering the recent legislative changes in both the US [19] and the European Union [20] aiming to increase the development of medicines for use in the paediatric population. However, a number of factors could help to explain this, including that a number of conditions are not prevalent in this population (e.g ischaemic heart disease, cerebrovascular disease), and that it is prudent to gather enough data in adults before trying new medicines in children -although this should not postpone the conduct of appropriate studies. Trials should pursue the acquisition of data, but at the same time should not pose youngsters to unnecessary risks. The fact that $40 \%$ of phase 1 and/or 2 trials on malaria were on or accepted minors is encouraging. 
In any case, many reports are being published pointing out specific challenges and needs (and approaches to address them) regarding the diseases considered in this analysis in the paediatric population [21-25].

How to label a given trial, as phase 1 or as phase 2, could be tricky. When a scientist is filling-in the CTG fields of a trial, he/she could use the rather simple (and short) definitions provided in CTG as guidance (Appendix A). However, scientists could follow more detailed definitions such as the ones provided by the ICH Tripartite Harmonised Guideline [26], in which phase 1 are mostly human pharmacology studies whereas phase 2 are typically therapeutic exploratory trials. Excluding cancer trials, this analysis shows that among phase 1 studies there were very similar number of healthy volunteer and patient trials -furthermore, some studies had both healthy and patients subjects-, and that a remarkable number were labelled as phase 1 and 2 trials. Seems that, in practice, the borders between both phases are getting blurred to some extent.

\section{Strengths and limitations}

This analysis has the limitation of being based on the trials registered in only one data base (CTG), although this is the largest (the number of registered studies in CTG being more than 10 times as much as the second one, ISRCTN [27]) and the most international one available. Currently $38 \%$ of all "open" "interventional" phase 1 and/or 2 trials with drugs and/or biologicals have no US participation, this figure being $44 \%$ when considering only the 16 leading causes of mortality. A second limitation is the difficulty to assess how the "conditions" in CTG correspond exactly to the WHO's "leading causes of death". In most instances, there was no problem in making this 
match. However, in diseases like ischemic heart disease and cerebrovascular disease, some trials could have been lost in the search performed in CTG. This, however, should not have impacted the overall results obtained, since to fulfil the aim of the analysis it was not necessary to include all the studies, but the majority.

Finally, another limitation could come from the inconsistencies and errors that scientists could have made when filling-in CTG fields. Thus, inconsistencies could be found in some cases such as, for instance, a phase 1 (NCT00492102) and a phase 2 (NCT00238056) trials on prematurity and low birth weight that accepted seniors. Few trials labelled as phase 1 could be more appropriate to be labelled as phase 2 . Thus, for example, study NCT00783107, a randomised, double-blind, placebo-controlled trial aimed to "evaluate the safety and effectiveness of aerosol cyclosporine" in treating COPD patients, or study NCT00476918, a randomised, double-blind, high vs low triamcinolone acetonide dose, to assess the "visual acuity, number of treatments and duration of efficacy" for the treatment of diabetic macular edema, seemed more phase 2 studies than phase 1 ones. Although 136 trials on healthy volunteers were also labelled as phase 1, 122 other healthy volunteer trials were not labelled as such. Among these there were errors like three nephrosis or nephritis trials (NCT00298506, NCT00302536 and NCT00302523) that were labelled as admitting healthy volunteers as participants but were in fact opened only for patients; these three studies were conducted at the same University, two of them by the same study director. Also, occasionally there were errors derived from key words that could prevent a correct search. Thus, for instance, NCT00955344 is a study aiming to assess if a behavioural intervention increases physician rates of colorectal cancer recommendation -but appeared in this search that was focussed only on trials with drugs and/or biologicals. Again, acknowledging this has happened (and will happen in the future) the impact should be limited since the 
analysis included both phase 1 and 2 trials -and those healthy volunteer ones with no labelled phase. A different scenario would have been if only phase 1 trials were included in the study, due to the confusion that could arise between phase 1 and or 2 in labelling some studies.

It is worth mentioning that the analysis was based in 2004 leading causes of death, which will continue to be an important source of mortality and morbidity in the two decades to come. Thus, 11 of the diseases considered are among the 15 leading causes of mortality projected in 2030 [10], whereas 5 of them are among the top 10 of the projected major causes of disability adjusted life years [10]. It should be bore in mind the high burden of disability caused by mental diseases, albeit none of them were among the 20 leading causes of death [7]. With this respect, unipolar depressive disorders are projected to be the second worldwide cause of disability adjusted life years in 2030, and to be among the three top leading causes of disability in high-, middle- and low-income countries [10].

The number of registered healthy volunteer studies seems rather low and was clustered in three conditions (diabetes, HIV/AIDS and respiratory tract infections) accounting for $71 \%$ of all trials. It's difficult to assess the extent of "open" healthy volunteer studies that were not registered on CTG. Bioequivalence trials (aimed to gather data for generic products marketing authorization) are usually not registered since, most likely, sponsors are not interested in publishing the results in peer-reviewed journals. Even taken this into consideration, 256 healthy volunteers studies seems surprisingly low, with conditions like hypertensive heart disease and cerebrovascular disease with only 1 and 4 “open" trials, respectively. Maybe the WHO [4] request to register phase 1 trials has not yet been widely followed by researchers when dealing with healthy volunteer trials. 


\section{Conclusions}

It is of concern to observe that more than $2 / 3$ of currently "open" early-phase trials were in only 4 of the 16 leading causes of death considered in this analysis. Furthermore, $45 \%$ of all phase 1 and/or 2 were on cancers, being a top priority for all sponsors. Although acknowledging that neoplasms will continue to be a leading cause of mortality in the years to come, and that behavioural individual (e.g. smoking, diet, physical activity) and community (e.g. sanitation) interventions have to play a major role in the prevention and management of the vast majority of these 16 diseases, seems rather disappointing to observe that early clinical research with new medicines, new combination regimens and new approaches with drugs and/or biologicals was fairly scarce in conditions afflicting millions of people globally. With this regard, it was surprising the relatively few "open" trials conducted on the three of the five major projected causes of death in 2030 in high-, middle- and low-income countries [10], i. e. ischaemic heart disease, cerebrovascular disease and COPD. On the contrary, it was encouraging to observe the increasing effort against malaria, although there are yet many issues to be addressed [28]. 
Competing interests

The author declares having no conflict of interests

$\underline{\text { Financial support }}$

This study required no financial support

$\underline{\text { Abbreviations }}$

CTG: Clinicaltrials.gov

FDA: US Food and Drug Administration

FED: US National Institutes of Health and Other US Federal Agency

HIV/AIDS: Human Immunodeficiency Virus/Acquired Immune Deficiency Syndrome

ICMJE: International Committee of Medical Journal Editors

INY: Industry

UNO: University / Organization: all others, including community-based organizations

WHO: World Health Organisation 
1.- De Angelis C, Drazen JM, Frizelle FA, Haug C, Hoey J et al. (2004) International Committee of Medical Journal Editors. Clinical trial registration: a statement from the International Committee of Medical Journal Editors. Ann Intern Med 141: 477-8.

2.- Gulmezoglu AM, Pang T, Horton R, Dickersin K. (2005) WHO facilitates international collaboration in setting standards for clinical trial registration. Lancet 365 : $1829-30$

3.- Sim I, Chan AW, Gulmezoglu AM, Evans T, Pang T. (2006) Clinical trial registration: transparency is the watchword. Lancet 367: 1631-3

4.- World Health Organization. International Clinical Trials Registry Platform (ICTRP) http://www.who.int/ictrp/en/ (accessed on May 10 ${ }^{\text {th }}, 2010$ )

5.- United States National Institutes of Health. http://Clinicaltrials.gov

6.- Zarin DA, Tre I, Ide NC. (2005) Trial registration at ClinTrials.gov between May and October 2005. N Engl J Med 353: 2779-87

7.- World Health Organization. (2008) "Global Burden of Disease, 2004 update”. http://www.who.int/healthinfo/global_burden_disease/2004_report_update/en/index.ht $\underline{\mathrm{ml}}$ (accessed on May 10 $\left.{ }^{\text {th }}, 2010\right)$

8.- World Health Organization. International Statistical Classification of Diseases and Related Health Problems. 10th Revision. Version for 2007. http://apps.who.int/classifications/apps/icd/icd10online/ (accessed May 10th, 2010) 9.- Zarin DA, Ide NC, Tse T, Harlan WR, West JC, Lindberg DAB.(2007) Issues in the registration of clinical trials. JAMA 297: 2112-20 
10.- Mathers CD, Loncar D. (2006) Projections of global mortality and burden of disease from 2002 to 2030. PLoS Med 3 (11): e442

11.- Tan DS, Thomas GV, Garrett MD, Banerji U, de Bono JS, et al (2009) Biomarkerdriven early clinical trials in oncology: a paradigm shift in drug development. Cancer J. 15: 406-20

12.- Müllner M, Vamvakas S, Rietschel M, van Zwieten-Boot BJ. (2007) Are women appropriately represented and assessed in clinical trials submitted for marketing authorization? A review of the database of the European Medicines Agency. Int J Clin Pharmacol Ther. 45: 477-84.

13.- Yang Y, Carlin AS, Faustino PJ, Motta MI, Hamad ML et al. (2009) Participation of women in clinical trials for new drugs approved by the Food and Drug Administration in 2000-2002. J Womens Health (Larchmt). 18: 303-10 14.- Fleish J, Fleish MC, Thürmann PA. (2005) Women in early-phase clinical drug trials: Have things changed over the past 20 years?. Clin Pharmacol Ther 78: 445-52 15.- Pinnow E, Sharma P, Parekh A, Gevorkian N, Uhl K. (2009) Increasing participation of women in early phase clinical trials approved by the FDA. Womens Health Issues. 19: 89-93.

16.- McMurdo M, Witham MD, Gillespie ND. (2005) Including older people in clinical research. Benefits shown in trials in younger people may not apply to older people. BMJ 331: 1036-1037.

17.-Talarico L, Chen G, Pazdur R. (2004) Enrollment of elderly patients in clinical trials for cancer drug registration: a 7-year experience by the US Food and Drug Administration. J Clin Oncol. 22: 4626-31. 
18.- Townsley CA, Chan KK, Pond GR, Marquez C, Siu LL, Straus SE. (2006)

Understanding the attitudes of the elderly towards enrolment into cancer clinical trials. BMC Cancer. 6: 34.

19.- Best Pharmaceuticals for Children Act, January 4, 2002. Public Law No. 107-109. http://www.fda.gov/Drugs/DevelopmentApprovalProcess/DevelopmentResources/ucm0 49867.htm. (Accessed on May 10 ${ }^{\text {th }}, 2010$ )

20.- Regulation (EC) No 1901/2006 of the European Parliament and of the Council of 12 December 206 on medicinal products for paediatric use and amending Regulation (EEC) No 1768/92, Directive 2001/20/EC, Directive 2001/83/EC and Regulation (EC) No 728/2004. Official Journal of the European Union. 27.12.2006. L378/1-18 21.- Nader NS, Kumar S. (2008) Type 2 diabetes mellitus in children and adolescents: where do we stand with drug treatment and behavioral management? Curr Diab Rep. 8: $383-8$.

22.- Zwaan CM, Kearns P, Caron H, Verschuur A, Riccardi R, et al. (2010) 'Innovative therapies for children with cancer' European consortium. The role of the 'innovative therapies for children with cancer' (ITCC) European consortium. Cancer Treat Rev. 36:328-34

23.- Swaminathan S, Rekha B. (2010) Pediatric tuberculosis: global overview and challenges. Clin Infect Dis. 50 Suppl 3:S184-94.

24.- Sohn AH, Nuttall JJ, Zhang F. (2010) Sequencing of antiretroviral therapy in children in low- and middle-income countries. Curr Opin HIV AIDS. 5: 54-60 25.- Theodoratou E, Al-Jilaihawi S, Woodward F, et al. (2010) The effect of case management on childhood pneumonia mortality in developing countries. Int $\mathbf{J}$ Epidemiol. 39 (Suppl 1): i155-71. 
26.- International Conference on Harmonisation of technical requirements for registration of pharmaceuticals for human use. ICH Harmonised Tripartite Guideline. General Considerations for clinical trials. E8; 17 July 1997. Available at http://www.ich.org/LOB/media/MEDIA484.pdf and US Federal Register 1997, 62: $66113-9$, at http://www.fda.gov/downloads/Drugs/GuidanceComplianceRegulatoryInformation/Gui dances/ucm073132.pdf (Accessed May 10 ${ }^{\text {th }}, 2010$ )

27.- Current controlled trials. ISRCTN. http://www.controlled-trials.com/ (accessed March 12th 2010)

28.- Anon (2010) Malaria 2010: more ambition and accountability please. Lancet, 345: 1407 
Appendix A. Clinicaltrials.gov definitions

Recruitment Status. Also known as Enrollment Status. (...)

Full list of all possible recruitment status values:

“Open” recruitment status values: Recruiting, Not yet recruiting, or Available for expanded access.

Closed recruitment status values: Active, not recruiting, Completed, Terminated, Suspended, Withdrawn, Enrolling by invitation, Temporarily not available for expanded access, No longer available for expanded access, or Approved for marketing.

Study Type. There are three types of studies available in ClinicalTrials.gov:

"Interventional": Studies where individuals are assigned to receive specific interventions. Participants may receive diagnostic, therapeutic or other types of interventions. Assignment of the intervention may or may not be random. Individuals are tracked and biomedical and/or health outcomes are assessed.

Observational: Studies without an intervention. (...)

Expanded Access: Records describing the procedure for obtaining an experimental drug or device for patients who are failing on currently available treatments for their condition and also are unable to participate in ongoing clinical trials. (...)

\section{Conditions.}

Conditions usually refer to a disease, disorder, syndrome, illness, or injury. In

ClinicalTrials.gov, conditions include any health issue worth studying, such as lifespan, quality of life, health risks, etc.

Use this box to specify the conditions being studied.

Examples: lupus heart attack leukemia risk factors for breast cancer

\section{Interventions}

Interventions refer to the drug, vaccine, procedure, device, or other potential treatment being studied. Interventions can also include less intrusive possibilities such as surveys, education, and interviews.

Use this box to specify drugs, devices, procedures, or vaccines used in a trial.

Examples: clofibrate cyclosporine vitamin e

\section{Funded By}

Studies are supported by one or more organizations called sponsors. Support includes contributions of facilities, expertise, and/or financial resources. All sponsors in the database have been assigned one of the following organization types:

“National Institutes of Health" (NIH) 
“Other U.S. Federal Agency" - Food and Drug Administration (FDA), Centers for Disease Control and Prevention (CDC), Department of Veterans Affairs (VA), etc.

"Industry" - the pharmaceutical companies

"University/Organization" - all others, including community-based organizations

$(\ldots)$ 
Table 1.- Sixteen of the 20 World Health Organisation's "leading causes of death" [7] and corresponding "conditions" as per Clinicaltrials.gov terminologies, respectively

\begin{tabular}{|l|l|}
\hline Leading causes of death / (\% of the total) [7] & Conditions (Clinicaltrials.gov) \\
\hline Ischaemic heart disease / (12.2)* & Myocardial ischemia, myocardial infarction (MIO) \\
\hline Cerebrovascular disease / (9.7)* & Cerebral infarction, stroke (CBD) \\
\hline Lower respiratory infections / (7.1)* & Respiratory tract infections (RTI) \\
\hline COPD / (5.1)* & $\begin{array}{l}\text { COPD, Chronic obstructive pulmonary disease } \\
\text { (COP) }\end{array}$ \\
\hline Diarrhoeal diseases / (3.7)* & Diarrhea (DIA) \\
\hline HIV/AIDS / (3.5) $*$ & $\begin{array}{l}\text { HIV/AIDS, Acquired immunodeficiency syndrome } \\
(\text { HIV) }\end{array}$ \\
\hline Tuberculosis / (2.5) $*$ & Tuberculosis (TBC) \\
\hline Trachea, bronchus, lung cancers / (2.3) & Respiratory tract neoplasms (RTN) \\
\hline Prematurity and low birth weight / (2.0)* & Prematurity, low birth weight (PLW) \\
\hline Diabetes mellitus / (1.9) & Diabetes mellitus (DBM) \\
\hline Hypertensive heart disease / (1.7) & Heart failure, Hypertensive heart disease (HFA) \\
\hline Malaria / (1.5) * & Malaria (MAL) \\
\hline Stomach cancer / (1.4) & Stomach neoplasms (STN) \\
\hline Cirrhosis of the liver / (1.3) & Liver cirrhosis (LVC) \\
\hline Nephritis and nephrosis / (1.3) & Nephritis, nephrosis (N\&N) \\
\hline Colon and rectum cancers / (1,1) & Colorectal cancer (CRC) \\
\hline
\end{tabular}

* Among the 10 top causes of death in low-income countries

COPD: Chronic obstructive pulmonary disease

HIV: Human immunodeficiency virus

AIDS: Acquired immunodeficiency syndrome 
Table 2.- Number (\%) of phase 1 and 2 trials distributed by Clinicaltrials.gov's "condition” corresponding to World Health Organisation's

"leading causes of death" [7]

\begin{tabular}{|c|c|c|c|c|c|c|c|c|c|c|c|c|c|c|c|c|c|c|}
\hline Trials & Trials & MIO & CBD & RTI & COP & DIA & HIV & TBC & RTN & PLW & DBM & HFA & MAL & STN & LVC & $\mathbf{N \& N}$ & CRC & Total \\
\hline \multirow[t]{6}{*}{ Phase 1} & Total A & $\begin{array}{l}25 \\
(3.0)\end{array}$ & $\begin{array}{l}19 \\
(2.3)\end{array}$ & $\begin{array}{l}62 \\
(7.5)\end{array}$ & $\begin{array}{l}12 \\
(1.5)\end{array}$ & $\begin{array}{l}5 \\
(0.6)\end{array}$ & $\begin{array}{l}115 \\
(14.0)\end{array}$ & $\begin{array}{l}17 \\
(2.0)\end{array}$ & $\begin{array}{l}184 \\
(22.3)\end{array}$ & $\begin{array}{l}12 \\
(1.5)\end{array}$ & $\begin{array}{l}153 \\
(18.6)\end{array}$ & $\begin{array}{l}26 \\
(3.2)\end{array}$ & $\begin{array}{l}27 \\
(3.3)\end{array}$ & $\begin{array}{l}31 \\
(3.8)\end{array}$ & $\begin{array}{l}14 \\
(1.7)\end{array}$ & $\begin{array}{l}6 \\
(0.7)\end{array}$ & $\begin{array}{l}116 \\
(14.1)\end{array}$ & 824 \\
\hline & $\begin{array}{l}\text { With Healthy } \\
\text { Volunteers (a)(b) }\end{array}$ & $\begin{array}{l}7 \\
(2.7)\end{array}$ & $\begin{array}{l}3 \\
(1.2)\end{array}$ & $\begin{array}{l}42 \\
(16.3)\end{array}$ & $\begin{array}{l}7 \\
(2.7)\end{array}$ & $\begin{array}{l}5 \\
(1.9)\end{array}$ & $\begin{array}{l}53 \\
(20.6)\end{array}$ & $\begin{array}{l}11 \\
(4.3)\end{array}$ & $\begin{array}{l}1(0.4) \\
(d)\end{array}$ & $\begin{array}{l}3 \\
(1.2)\end{array}$ & $\begin{array}{l}90 \\
(34.9)\end{array}$ & $\begin{array}{l}4 \\
(1.6)\end{array}$ & $\begin{array}{l}27 \\
(10.5)\end{array}$ & 0 & $\begin{array}{l}4 \\
(1.6)\end{array}$ & 0 & $\begin{array}{l}1(0.4) \\
(d)\end{array}$ & 258 \\
\hline & Phases $1 \& 2$ (a) & $\begin{array}{l}8 \\
(2.7)\end{array}$ & $\begin{array}{l}8 \\
(2.7)\end{array}$ & $\begin{array}{l}14 \\
(4.8)\end{array}$ & $\begin{array}{l}1 \\
(0.3)\end{array}$ & $\begin{array}{l}1 \\
(0.3)\end{array}$ & $\begin{array}{l}65 \\
(22.0)\end{array}$ & $\begin{array}{l}3 \\
(1.0)\end{array}$ & $\begin{array}{l}78 \\
(26.4)\end{array}$ & $\begin{array}{l}3 \\
(1.0)\end{array}$ & $\begin{array}{l}26 \\
(8.8)\end{array}$ & $\begin{array}{l}12 \\
(4.1)\end{array}$ & $\begin{array}{l}6 \\
(2.0)\end{array}$ & $\begin{array}{l}14 \\
(4.8)\end{array}$ & $\begin{array}{l}4 \\
(1.4)\end{array}$ & $\begin{array}{l}3 \\
(1.0)\end{array}$ & $\begin{array}{l}49 \\
(16.6)\end{array}$ & 295 \\
\hline & Drugs & $\begin{array}{l}17 \\
(2.5)\end{array}$ & $\begin{array}{l}16 \\
(2.4)\end{array}$ & $\begin{array}{l}34 \\
(5.0)\end{array}$ & $\begin{array}{l}12 \\
(1.8)\end{array}$ & $\begin{array}{l}2 \\
(0.3)\end{array}$ & $\begin{array}{l}87 \\
(12.9)\end{array}$ & $\begin{array}{l}12 \\
(1.8)\end{array}$ & $\begin{array}{l}163 \\
(24.1)\end{array}$ & $\begin{array}{l}12 \\
(1.8)\end{array}$ & $\begin{array}{l}142 \\
(20.1)\end{array}$ & $\begin{array}{l}17 \\
(2.5)\end{array}$ & $\begin{array}{l}18 \\
(2.7)\end{array}$ & $\begin{array}{l}29 \\
(4.3)\end{array}$ & $\begin{array}{l}12 \\
(1.8)\end{array}$ & $\begin{array}{l}3 \\
(0.5)\end{array}$ & $\begin{array}{l}101 \\
(14.9)\end{array}$ & 677 \\
\hline & Biologicals & $\begin{array}{l}8 \\
(4.0)\end{array}$ & $\begin{array}{l}4 \\
(2.0)\end{array}$ & $\begin{array}{l}30 \\
(15.6)\end{array}$ & 0 & $\begin{array}{l}4 \\
(2.0)\end{array}$ & $\begin{array}{l}34 \\
(17.1)\end{array}$ & $\begin{array}{l}6 \\
(3.0)\end{array}$ & $\begin{array}{l}38 \\
(19.1)\end{array}$ & 0 & $\begin{array}{l}12 \\
(6.0)\end{array}$ & $\begin{array}{l}9 \\
(4.5)\end{array}$ & $\begin{array}{l}13 \\
(6.5)\end{array}$ & $\begin{array}{l}3 \\
(1.5)\end{array}$ & $\begin{array}{l}2 \\
(2.0)\end{array}$ & $\begin{array}{l}3 \\
(1.5)\end{array}$ & $\begin{array}{l}33 \\
(16.6)\end{array}$ & 199 \\
\hline & $\begin{array}{l}\text { Drugs \& } \\
\text { Biologicals }\end{array}$ & 0 & $\begin{array}{l}1 \\
(1.9)\end{array}$ & $2(3.9)$ & 0 & $\begin{array}{l}1 \\
(1.9)\end{array}$ & $\begin{array}{l}6 \\
(11.5)\end{array}$ & $\begin{array}{l}1 \\
(1.9)\end{array}$ & $\begin{array}{l}17 \\
(32.7)\end{array}$ & 0 & $1(1.9)$ & 0 & $\begin{array}{l}4 \\
(7.7)\end{array}$ & $\begin{array}{l}1 \\
(1.9)\end{array}$ & 0 & 0 & $\begin{array}{l}18 \\
(34.6)\end{array}$ & 52 \\
\hline \multirow[t]{3}{*}{ Phase 2} & Total B & $\begin{array}{l}78 \\
(5.3)\end{array}$ & $\begin{array}{l}43 \\
(2.9)\end{array}$ & $\begin{array}{l}99 \\
(6.7)\end{array}$ & $\begin{array}{l}33 \\
(2.2)\end{array}$ & $\begin{array}{l}13 \\
(0.9)\end{array}$ & $\begin{array}{l}168 \\
(11.4)\end{array}$ & $\begin{array}{l}23 \\
(1.6)\end{array}$ & $\begin{array}{l}390 \\
(26.5)\end{array}$ & $\begin{array}{l}17 \\
(1.2)\end{array}$ & $\begin{array}{l}193 \\
(13.1)\end{array}$ & $\begin{array}{l}62 \\
(4.2)\end{array}$ & $\begin{array}{l}15 \\
(1.0)\end{array}$ & $\begin{array}{l}91 \\
(6.2)\end{array}$ & $\begin{array}{l}17 \\
(1.2)\end{array}$ & $\begin{array}{l}15 \\
(1.0)\end{array}$ & $\begin{array}{l}217 \\
(14.7)\end{array}$ & 1474 \\
\hline & Phases $2 \& 3$ (c) & $\begin{array}{l}20 \\
(11.3)\end{array}$ & $\begin{array}{l}11 \\
(0.8)\end{array}$ & $\begin{array}{l}25 \\
(14.1)\end{array}$ & $\begin{array}{l}7 \\
(4.0)\end{array}$ & $\begin{array}{l}5 \\
(2.8)\end{array}$ & $\begin{array}{l}17 \\
(9.6)\end{array}$ & $\begin{array}{l}2 \\
(1.1)\end{array}$ & $\begin{array}{l}10 \\
(5.7)\end{array}$ & $\begin{array}{l}6 \\
(3.4)\end{array}$ & $\begin{array}{l}33 \\
(18.7)\end{array}$ & $\begin{array}{l}13 \\
(7.4)\end{array}$ & $\begin{array}{l}8 \\
(4.5)\end{array}$ & $\begin{array}{l}4 \\
(2.3)\end{array}$ & $\begin{array}{l}6 \\
(3.4)\end{array}$ & $\begin{array}{l}2 \\
(1.1)\end{array}$ & $7(4.0)$ & 177 \\
\hline & Drugs & $\begin{array}{l}64 \\
(4.8)\end{array}$ & $\begin{array}{l}41 \\
(3.1)\end{array}$ & $\begin{array}{l}69 \\
(5.1)\end{array}$ & $\begin{array}{l}33 \\
(2.5)\end{array}$ & $\begin{array}{l}99 \\
(0.7)\end{array}$ & $\begin{array}{l}141 \\
(10.5)\end{array}$ & $\begin{array}{l}20 \\
(1.5)\end{array}$ & $\begin{array}{l}375 \\
(27.9)\end{array}$ & $\begin{array}{l}17 \\
(1.3)\end{array}$ & $\begin{array}{l}187 \\
(13.9)\end{array}$ & $\begin{array}{l}50 \\
(3.7)\end{array}$ & $\begin{array}{l}9 \\
(0.7)\end{array}$ & $\begin{array}{l}89 \\
(6.6)\end{array}$ & $\begin{array}{l}17 \\
(1.3)\end{array}$ & $\begin{array}{l}13 \\
(1.0)\end{array}$ & $\begin{array}{l}210 \\
(15.6)\end{array}$ & 1344 \\
\hline
\end{tabular}




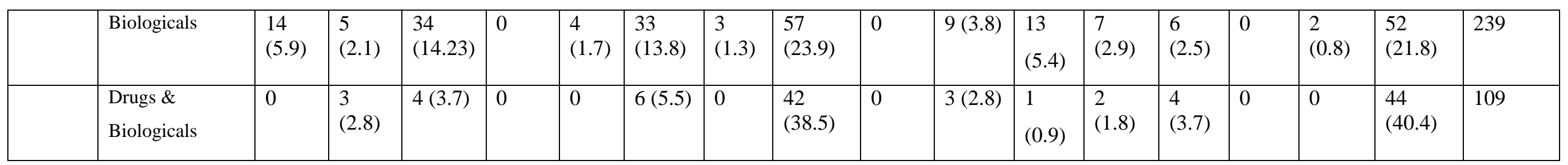

(a) These are included in Total A; (b) Some trials admitted healthy volunteers and patients; (c) These are included in Total B; (d) Study accepting healthy volunteers and patients

MIO: Ischaemic heart disease; CBD: Cerebrovascular disease; RTI: Lower respiratory infections; COP: Chronic obstructive pulmonary disease; DIA:

Diarrhoeal diseases; HIV: HIV/AIDS; TBC: Tuberculosis; RTN: Trachea, bronchus, lung cancers; PLW: Prematurity and low birth weight; DBM: Diabetes mellitus; HFA: Heart failure; MAL: Malaria; LVC: Cirrhosis of the liver; N\&N: nephritis and nephrosis; CRC: Colon and rectum cancers 
Table 3.- Number (\%) of phase 1 and 2 trials distributed by Clinicaltrials.gov's “condition” corresponding to World Health Organisation's

"leading causes of death" [7] and by funding source

\begin{tabular}{|c|c|c|c|c|c|c|c|c|c|c|c|c|c|c|c|c|c|c|}
\hline & & MIO & CBD & RTI & COP & DIA & HIV & TBC & RTN & PLW & DBM & HFA & MAL & STN & LVC & $\mathbf{N \& N}$ & CRC & Total* \\
\hline Phase 1 & No of trials & $\begin{array}{l}25 \\
(3.0)\end{array}$ & $\begin{array}{l}19 \\
(2.3)\end{array}$ & $\begin{array}{l}62 \\
(7.5)\end{array}$ & $\begin{array}{l}12 \\
(1.5)\end{array}$ & $\begin{array}{l}5 \\
(0.6)\end{array}$ & $\begin{array}{l}115 \\
(14.0)\end{array}$ & $\begin{array}{l}17 \\
(2.0)\end{array}$ & $\begin{array}{l}184 \\
(22.3)\end{array}$ & $\begin{array}{l}12 \\
(1.5)\end{array}$ & $\begin{array}{l}153 \\
(18.6)\end{array}$ & $\begin{array}{l}26 \\
(3.2)\end{array}$ & $\begin{array}{l}27 \\
(3.3)\end{array}$ & $\begin{array}{l}31 \\
(3.8)\end{array}$ & $\begin{array}{l}14 \\
(1.7)\end{array}$ & $\begin{array}{l}6 \\
(0.7)\end{array}$ & $\begin{array}{l}116 \\
(14.1)\end{array}$ & 824 \\
\hline \multirow[t]{3}{*}{ Funding } & FED & $\begin{array}{l}3 \\
(1.4)\end{array}$ & $\begin{array}{l}3 \\
(1.4)\end{array}$ & $\begin{array}{l}20 \\
(9.0)\end{array}$ & $\begin{array}{l}2 \\
(0.9)\end{array}$ & $\begin{array}{l}3 \\
(1.4)\end{array}$ & $\begin{array}{l}56 \\
(25.1)\end{array}$ & $\begin{array}{l}6 \\
(2.7)\end{array}$ & $\begin{array}{l}46 \\
(20.6)\end{array}$ & $\begin{array}{l}3 \\
(1.4)\end{array}$ & $\begin{array}{l}27 \\
(12.1)\end{array}$ & $\begin{array}{l}8 \\
(3.6)\end{array}$ & $\begin{array}{l}10 \\
(4.5)\end{array}$ & $\begin{array}{l}8 \\
(3.6)\end{array}$ & $\begin{array}{l}3 \\
(1.4)\end{array}$ & 0 & $\begin{array}{l}25 \\
(11.2)\end{array}$ & 223 \\
\hline & INY & $\begin{array}{l}6 \\
(1.8)\end{array}$ & $\begin{array}{l}5 \\
(1.5)\end{array}$ & $\begin{array}{l}19 \\
(5.8)\end{array}$ & $\begin{array}{l}7 \\
(2.2)\end{array}$ & 0 & $\begin{array}{l}28 \\
(8.6)\end{array}$ & $\begin{array}{l}4 \\
(1.2)\end{array}$ & $\begin{array}{l}89 \\
(27.3)\end{array}$ & $\begin{array}{l}4 \\
(1.2)\end{array}$ & $\begin{array}{l}69 \\
(21.2)\end{array}$ & $\begin{array}{l}10 \\
(3.1)\end{array}$ & $\begin{array}{l}2 \\
(0.6)\end{array}$ & $\begin{array}{l}12 \\
(3.7)\end{array}$ & $\begin{array}{l}4 \\
(1.2)\end{array}$ & $\begin{array}{l}4 \\
(1.2)\end{array}$ & $\begin{array}{l}63 \\
(19.3)\end{array}$ & 326 \\
\hline & UNO & $\begin{array}{l}22 \\
(4.6)\end{array}$ & $\begin{array}{l}16 \\
(3.3)\end{array}$ & $\begin{array}{l}34 \\
(7.0)\end{array}$ & $\begin{array}{l}4 \\
(0.8)\end{array}$ & $\begin{array}{l}4 \\
(0.8)\end{array}$ & $\begin{array}{l}56 \\
(11.6)\end{array}$ & $\begin{array}{l}10 \\
(2.1)\end{array}$ & $\begin{array}{l}107 \\
(22.1)\end{array}$ & $\begin{array}{l}99 \\
(1.9)\end{array}$ & $\begin{array}{l}86 \\
(17.8)\end{array}$ & $\begin{array}{l}16 \\
(3.3)\end{array}$ & $\begin{array}{l}19 \\
(3.9)\end{array}$ & $\begin{array}{l}18 \\
(3.7)\end{array}$ & $\begin{array}{l}11 \\
(2.3)\end{array}$ & $\begin{array}{l}3 \\
(0.6)\end{array}$ & $\begin{array}{l}69 \\
(14.3)\end{array}$ & 484 \\
\hline \multirow[t]{3}{*}{$\begin{array}{l}\text { Co- } \\
\text { funding }\end{array}$} & FED\&INY & $\begin{array}{l}3 \\
(10.3)\end{array}$ & $\begin{array}{l}1 \\
(4.8)\end{array}$ & $\begin{array}{l}4 \\
(19.1)\end{array}$ & 0 & 0 & $\begin{array}{l}4 \\
(19.1)\end{array}$ & $\begin{array}{l}1 \\
(4.8)\end{array}$ & $1(4.8)$ & $\begin{array}{l}2 \\
(9.5)\end{array}$ & $\begin{array}{l}2 \\
(9.5)\end{array}$ & $\begin{array}{l}2 \\
(9.5)\end{array}$ & 0 & 0 & 0 & 0 & $\begin{array}{l}1 \\
(4.8)\end{array}$ & 21 \\
\hline & FED\&UNO & $\begin{array}{l}3 \\
(2.5)\end{array}$ & $\begin{array}{l}3 \\
(2.5)\end{array}$ & $\begin{array}{l}8 \\
(6.6)\end{array}$ & $\begin{array}{l}2 \\
(1.6)\end{array}$ & $\begin{array}{l}2 \\
(1.6)\end{array}$ & $\begin{array}{l}17 \\
(13.9)\end{array}$ & $\begin{array}{l}2 \\
(1.6)\end{array}$ & $\begin{array}{l}31 \\
(25.4)\end{array}$ & $\begin{array}{l}1 \\
(0.8)\end{array}$ & $\begin{array}{l}18 \\
(14.8)\end{array}$ & $\begin{array}{l}5 \\
(4.1)\end{array}$ & $\begin{array}{l}4 \\
(3.3)\end{array}$ & $\begin{array}{l}6 \\
(4.9)\end{array}$ & $\begin{array}{l}2 \\
(1.6)\end{array}$ & 0 & $\begin{array}{l}18 \\
(14.8)\end{array}$ & 122 \\
\hline & INY\&UNO & $\begin{array}{l}4 \\
(3.9)\end{array}$ & $\begin{array}{l}2 \\
(2.0)\end{array}$ & $\begin{array}{l}5 \\
(4.9)\end{array}$ & 0 & 0 & $\begin{array}{l}8 \\
(7.9)\end{array}$ & $\begin{array}{l}1 \\
(1.0)\end{array}$ & $\begin{array}{l}30 \\
(29.4)\end{array}$ & $\begin{array}{l}2 \\
(2.0)\end{array}$ & $\begin{array}{l}13 \\
(12.8)\end{array}$ & $\begin{array}{l}5 \\
(4.9)\end{array}$ & $\begin{array}{l}2 \\
(2.0)\end{array}$ & $\begin{array}{l}1 \\
(1.0)\end{array}$ & $\begin{array}{l}2 \\
(2.0)\end{array}$ & $\begin{array}{l}2 \\
(2.0)\end{array}$ & $\begin{array}{l}25 \\
(24.5)\end{array}$ & 102 \\
\hline Phase 2 & No of trials & $\begin{array}{l}78 \\
(5.3)\end{array}$ & $\begin{array}{l}43 \\
(2.9)\end{array}$ & $\begin{array}{l}99 \\
(6.7)\end{array}$ & $\begin{array}{l}33 \\
(2.2)\end{array}$ & $\begin{array}{l}13 \\
(0.9)\end{array}$ & $\begin{array}{l}168 \\
(11.4)\end{array}$ & $\begin{array}{l}23 \\
(1.6)\end{array}$ & $\begin{array}{l}390 \\
(26.5)\end{array}$ & $\begin{array}{l}17 \\
(1.2)\end{array}$ & $\begin{array}{l}193 \\
(13.1)\end{array}$ & $\begin{array}{l}62 \\
(4.2)\end{array}$ & $\begin{array}{l}15 \\
(1.0)\end{array}$ & $\begin{array}{l}91 \\
(6.2)\end{array}$ & $\begin{array}{l}17 \\
(1.2)\end{array}$ & $\begin{array}{l}15 \\
(1.0)\end{array}$ & $\begin{array}{l}217 \\
(14.7)\end{array}$ & 1474 \\
\hline Funding & FED & $\begin{array}{l}8 \\
(2.8)\end{array}$ & $\begin{array}{l}8 \\
(2.8)\end{array}$ & $\begin{array}{l}19 \\
(6.5)\end{array}$ & $\begin{array}{l}5 \\
(1.7)\end{array}$ & $\begin{array}{l}2 \\
(0.7)\end{array}$ & $\begin{array}{l}68 \\
(23.4)\end{array}$ & $\begin{array}{l}6 \\
(2.1)\end{array}$ & $\begin{array}{l}81 \\
(27.8)\end{array}$ & $\begin{array}{l}2 \\
(0.7)\end{array}$ & $\begin{array}{l}32 \\
(11.0)\end{array}$ & $\begin{array}{l}9 \\
(8.8)\end{array}$ & $\begin{array}{l}3 \\
(1.0)\end{array}$ & $\begin{array}{l}15 \\
(5.2)\end{array}$ & 0 & $\begin{array}{l}5 \\
(1.7)\end{array}$ & $\begin{array}{l}28 \\
(9.6)\end{array}$ & 291 \\
\hline
\end{tabular}




\begin{tabular}{|c|c|c|c|c|c|c|c|c|c|c|c|c|c|c|c|c|c|c|}
\hline & INY & $\begin{array}{l}32 \\
(5.1)\end{array}$ & $\begin{array}{l}32 \\
(5.1)\end{array}$ & $\begin{array}{l}49 \\
(7.8)\end{array}$ & $\begin{array}{l}23 \\
(3.7)\end{array}$ & $\begin{array}{l}7 \\
(1.1)\end{array}$ & $\begin{array}{l}47 \\
(7.5)\end{array}$ & $\begin{array}{l}8 \\
(1.3)\end{array}$ & $\begin{array}{l}176 \\
(28.0)\end{array}$ & $\begin{array}{l}3 \\
(0.5)\end{array}$ & $\begin{array}{l}101 \\
(16.1)\end{array}$ & $\begin{array}{l}26 \\
(4.1)\end{array}$ & $\begin{array}{l}5 \\
(0.8)\end{array}$ & $\begin{array}{l}35 \\
(5.6)\end{array}$ & \begin{tabular}{|l|}
6 \\
$(1.0)$
\end{tabular} & $\begin{array}{l}6 \\
(1.0)\end{array}$ & $\begin{array}{l}92 \\
(14.7)\end{array}$ & 628 \\
\hline & UNO & $\begin{array}{l}51 \\
(5.7)\end{array}$ & $\begin{array}{l}28 \\
(3.1)\end{array}$ & $\begin{array}{l}42 \\
(4.7)\end{array}$ & $\begin{array}{l}11 \\
(1.2)\end{array}$ & $\begin{array}{l}8 \\
(0.9)\end{array}$ & $\begin{array}{l}95 \\
(10.7)\end{array}$ & $\begin{array}{l}13 \\
(1.5)\end{array}$ & $\begin{array}{l}251 \\
(28.1)\end{array}$ & $\begin{array}{l}14 \\
(1.6)\end{array}$ & $\begin{array}{l}95 \\
(10.7)\end{array}$ & $\begin{array}{l}42 \\
(4.7)\end{array}$ & $\begin{array}{l}10 \\
(1.1)\end{array}$ & $\begin{array}{l}66 \\
(7.4)\end{array}$ & \begin{tabular}{|l}
13 \\
$(1.5)$
\end{tabular} & $\begin{array}{l}6 \\
(0.7)\end{array}$ & $\begin{array}{l}149 \\
(16.7)\end{array}$ & 894 \\
\hline \multirow[t]{3}{*}{$\begin{array}{l}\text { Co- } \\
\text { funding }\end{array}$} & FED\&INY & $\begin{array}{l}1 \\
(4.2)\end{array}$ & 0 & $\begin{array}{l}3 \\
(12.5)\end{array}$ & $\begin{array}{l}1 \\
(4.2)\end{array}$ & 0 & $\begin{array}{l}3 \\
(12.5)\end{array}$ & $\begin{array}{l}1 \\
(4.2)\end{array}$ & $\begin{array}{l}3 \\
(12.5)\end{array}$ & $\begin{array}{l}1 \\
(4.2)\end{array}$ & $\begin{array}{l}4 \\
(16.7)\end{array}$ & $\begin{array}{l}3 \\
(12.5)\end{array}$ & $\begin{array}{l}2 \\
(8.3)\end{array}$ & 0 & 0 & $\begin{array}{l}1 \\
(4.2)\end{array}$ & $\begin{array}{l}1 \\
(4.2)\end{array}$ & 24 \\
\hline & FED\&UNO & $\begin{array}{l}28 \\
(15.6)\end{array}$ & $\begin{array}{l}8 \\
(4.4)\end{array}$ & $\begin{array}{l}2 \\
(1.1)\end{array}$ & $\begin{array}{l}2 \\
(1.1)\end{array}$ & $\begin{array}{l}1 \\
(0.6)\end{array}$ & $\begin{array}{l}29 \\
(16.1)\end{array}$ & $\begin{array}{l}3 \\
(1.7)\end{array}$ & $\begin{array}{l}53 \\
(3.0)\end{array}$ & $\begin{array}{l}1 \\
(0.6)\end{array}$ & $\begin{array}{l}15 \\
(8.3)\end{array}$ & $\begin{array}{l}8 \\
(4.4)\end{array}$ & $\begin{array}{l}4 \\
(2.2)\end{array}$ & $\begin{array}{l}9 \\
(5.0)\end{array}$ & 0 & $\begin{array}{l}1 \\
(0.6)\end{array}$ & $\begin{array}{l}16 \\
(8.9)\end{array}$ & 180 \\
\hline & INY\&UNO & $\begin{array}{l}11 \\
(4.9)\end{array}$ & $\begin{array}{l}1 \\
(0.5)\end{array}$ & $\begin{array}{l}10 \\
(4.4)\end{array}$ & $\begin{array}{l}4 \\
(1.8)\end{array}$ & $\begin{array}{l}3 \\
(1.3)\end{array}$ & $\begin{array}{l}17 \\
(7.6)\end{array}$ & $\begin{array}{l}3 \\
(1.3)\end{array}$ & $\begin{array}{l}76 \\
(33.8)\end{array}$ & $\begin{array}{l}1 \\
(0.5)\end{array}$ & $\begin{array}{l}22 \\
(9.8)\end{array}$ & $\begin{array}{l}9 \\
(4.0)\end{array}$ & $\begin{array}{l}5 \\
(2.2)\end{array}$ & $\begin{array}{l}20 \\
(8.9)\end{array}$ & \begin{tabular}{|l}
3 \\
$(1.3)$
\end{tabular} & $\begin{array}{l}2 \\
(0.9)\end{array}$ & $\begin{array}{l}38 \\
(16.9)\end{array}$ & 225 \\
\hline
\end{tabular}

* Total No of different studies by "condition". Since some studies were funded by more than one "funding source", the sum of the studies funded by each source is greater than the total number of studies.

MIO: Ischaemic heart disease; CBD: Cerebrovascular disease; RTI: Lower respiratory infections; COP: Chronic obstructive pulmonary disease; DIA:

Diarrhoeal diseases; HIV: HIV/AIDS; TBC: Tuberculosis; RTN: Trachea, bronchus, lung cancers; PLW: Prematurity and low birth weight; DBM: Diabetes mellitus; HFA: Heart failure; MAL: Malaria; LVC: Cirrhosis of the liver; N\&N: nephritis and nephrosis; CRC: Colon and rectum cancers

FED: National Institutes of Health and Other US Federal Agency; INY: Industry; UNO: University/Organization 
Table 4.- Number (\%) of phase 1 and 2 trials distributed by Clinicaltrials.gov's “condition" corresponding to World Health Organisation's "leading causes of death" [7] by age groups and gender

\begin{tabular}{|c|c|c|c|c|c|c|c|c|c|c|c|c|c|c|c|c|c|c|}
\hline & & MIO & CBD & RTI & COP & DIA & HIV & TBC & RTN & PLW & DBM & HFA & MAL & STN & LVC & $\mathbf{N \& N}$ & CRC & Total* \\
\hline Phase 1 & No of trials & $\begin{array}{l}25 \\
(3.0)\end{array}$ & $\begin{array}{l}19 \\
(2.3)\end{array}$ & $\begin{array}{l}62 \\
(7.5)\end{array}$ & $\begin{array}{l}12 \\
(1.5)\end{array}$ & $\begin{array}{l}5 \\
(0.6)\end{array}$ & $\begin{array}{l}115 \\
(14.0)\end{array}$ & $\begin{array}{l}17 \\
(2.0)\end{array}$ & $\begin{array}{l}184 \\
(22.3)\end{array}$ & $\begin{array}{l}12 \\
(1.5)\end{array}$ & $\begin{array}{l}153 \\
(18.6)\end{array}$ & $\begin{array}{l}26 \\
(3.2)\end{array}$ & $\begin{array}{l}27 \\
(3.3)\end{array}$ & $\begin{array}{l}31 \\
(3.8)\end{array}$ & $\begin{array}{l}14 \\
(1.7)\end{array}$ & $6(0.7)$ & $\begin{array}{l}116 \\
(14.1)\end{array}$ & 824 \\
\hline \multirow[t]{3}{*}{ Age groups } & $\leq 17$ years old & $1(1.0)$ & $1(1.0)$ & $\begin{array}{l}19 \\
(19.6)\end{array}$ & 0 & $\begin{array}{l}2 \\
(2.1)\end{array}$ & $\begin{array}{l}18 \\
(18.6)\end{array}$ & $\begin{array}{l}2 \\
(2.1)\end{array}$ & $6(6.2)$ & $\begin{array}{l}10 \\
(10.3)\end{array}$ & $\begin{array}{l}15 \\
(15.5)\end{array}$ & $\begin{array}{l}2 \\
(2.1)\end{array}$ & $\begin{array}{l}10 \\
(10.3)\end{array}$ & $\begin{array}{l}2 \\
(2.1)\end{array}$ & $\begin{array}{l}2 \\
(2.1)\end{array}$ & $1(1.0)$ & $\begin{array}{l}6 \\
(6.2)\end{array}$ & 97 \\
\hline & Adults \& Seniors & $\begin{array}{l}25 \\
(3.2)\end{array}$ & $\begin{array}{l}16 \\
(2.1)\end{array}$ & $\begin{array}{l}49 \\
(6.3)\end{array}$ & $\begin{array}{l}12 \\
(1.6)\end{array}$ & $\begin{array}{l}4 \\
(0.5)\end{array}$ & $\begin{array}{l}110 \\
(14.2)\end{array}$ & $\begin{array}{l}15 \\
(1.9)\end{array}$ & $\begin{array}{l}184 \\
(23.7)\end{array}$ & $2(0.3)$ & $\begin{array}{l}149 \\
(19.2)\end{array}$ & $\begin{array}{l}26 \\
(3.4)\end{array}$ & $\begin{array}{l}20 \\
(2.6)\end{array}$ & $\begin{array}{l}31 \\
(4.0)\end{array}$ & $\begin{array}{l}13 \\
(1.7)\end{array}$ & $5(0.7)$ & $\begin{array}{l}116 \\
(14.9)\end{array}$ & 777 \\
\hline & Seniors & $\begin{array}{l}22 \\
(4.1)\end{array}$ & $\begin{array}{l}15 \\
(2.8)\end{array}$ & $\begin{array}{l}25 \\
(4.6)\end{array}$ & $\begin{array}{l}7(1.3) \\
\text { (d) }\end{array}$ & $\begin{array}{l}1 \\
(0.2)\end{array}$ & $\begin{array}{l}43 \\
(7.9)\end{array}$ & $\begin{array}{l}4 \\
(0.7)\end{array}$ & $\begin{array}{l}182 \\
(33.5)\end{array}$ & 0 & $\begin{array}{l}61 \\
(11.2)\end{array}$ & $\begin{array}{l}24 \\
(4.4)\end{array}$ & $2(0.4)$ & $\begin{array}{l}30 \\
(5.5)\end{array}$ & $\begin{array}{l}8 \\
(1.5)\end{array}$ & $5(0.9)$ & $\begin{array}{l}114 \\
(21.0)\end{array}$ & 543 \\
\hline \multirow[t]{2}{*}{ Gender } & $\begin{array}{l}\text { With female } \\
\text { participants }\end{array}$ & $\begin{array}{l}22 \\
(2.8)\end{array}$ & $\begin{array}{l}17 \\
(2.1)\end{array}$ & $\begin{array}{l}60 \\
(7.6)\end{array}$ & $\begin{array}{l}11 \\
(1.4)\end{array}$ & $\begin{array}{l}5 \\
(0.6)\end{array}$ & $\begin{array}{l}113 \\
(14.3)\end{array}$ & $\begin{array}{l}17 \\
(2.1)\end{array}$ & $\begin{array}{l}184 \\
(23.3)\end{array}$ & $\begin{array}{l}12 \\
(1.5)\end{array}$ & $\begin{array}{l}137 \\
(17.3)\end{array}$ & $\begin{array}{l}25 \\
(3.2)\end{array}$ & $\begin{array}{l}24 \\
(3.0)\end{array}$ & $\begin{array}{l}30 \\
(3.8)\end{array}$ & $\begin{array}{l}13 \\
(1.7)\end{array}$ & $5(0.6)$ & $\begin{array}{l}116 \\
(14.7)\end{array}$ & 791 \\
\hline & $\begin{array}{l}\text { With male } \\
\text { participant }\end{array}$ & $\begin{array}{l}25 \\
(3.2)\end{array}$ & $\begin{array}{l}17 \\
(2.2)\end{array}$ & $\begin{array}{l}57 \\
(7.3)\end{array}$ & $\begin{array}{l}12 \\
(1.5)\end{array}$ & $\begin{array}{l}5 \\
(0.6)\end{array}$ & $\begin{array}{l}103 \\
(13.1)\end{array}$ & $\begin{array}{l}16 \\
(2.0)\end{array}$ & $\begin{array}{l}184 \\
(23.4)\end{array}$ & $\begin{array}{l}10 \\
(1.3)\end{array}$ & $\begin{array}{l}144 \\
(18.3)\end{array}$ & $\begin{array}{l}26 \\
(3.3)\end{array}$ & $\begin{array}{l}23 \\
(2.9)\end{array}$ & $\begin{array}{l}31 \\
(3.9)\end{array}$ & $\begin{array}{l}13 \\
(1.7)\end{array}$ & $5(0.6)$ & $\begin{array}{l}116 \\
(14.7)\end{array}$ & 787 \\
\hline Phase 2 & No of trials & $\begin{array}{l}78 \\
(5.3)\end{array}$ & $\begin{array}{l}43 \\
(2.9)\end{array}$ & $\begin{array}{l}99 \\
(6.7)\end{array}$ & $\begin{array}{l}33 \\
(2.2)\end{array}$ & $\begin{array}{l}13 \\
(0.9)\end{array}$ & $\begin{array}{l}168 \\
(11.4)\end{array}$ & $\begin{array}{l}23 \\
(1.6)\end{array}$ & $\begin{array}{l}390 \\
(26.5)\end{array}$ & $\begin{array}{l}17 \\
(1.2)\end{array}$ & $\begin{array}{l}193 \\
(13.1)\end{array}$ & $\begin{array}{l}62 \\
(4.2)\end{array}$ & $\begin{array}{l}15 \\
(1.0)\end{array}$ & $\begin{array}{l}91 \\
(6.2)\end{array}$ & $\begin{array}{l}17 \\
(1.2)\end{array}$ & $\begin{array}{l}15 \\
(1.0)\end{array}$ & $\begin{array}{l}217 \\
(14.7)\end{array}$ & 1474 \\
\hline \multirow[t]{3}{*}{ Age groups } & $\leq 17$ years old & $4(2.3)$ & $2(1.2)$ & $\begin{array}{l}38 \\
(22.0)\end{array}$ & $2(1.2)$ & $\begin{array}{l}5 \\
(2.9)\end{array}$ & $\begin{array}{l}34 \\
(19.7)\end{array}$ & $\begin{array}{l}2 \\
(1.2)\end{array}$ & $\begin{array}{l}15 \\
(8.7)\end{array}$ & $\begin{array}{l}17 \\
(9.8)\end{array}$ & $\begin{array}{l}21 \\
(12.1)\end{array}$ & $\begin{array}{l}4 \\
(2.3)\end{array}$ & $7(4.0)$ & $\begin{array}{l}7 \\
(4.0)\end{array}$ & $\begin{array}{l}2 \\
(1.2)\end{array}$ & $5(2.9)$ & $\begin{array}{l}8 \\
(4.6) \mathrm{v}\end{array}$ & 173 \\
\hline & Adults \& Seniors & $\begin{array}{l}78 \\
(5.5)\end{array}$ & $\begin{array}{l}42 \\
(3.0)\end{array}$ & $\begin{array}{l}82 \\
(5.8)\end{array}$ & $\begin{array}{l}33 \\
(2.3)\end{array}$ & $\begin{array}{l}9 \\
(0.6)\end{array}$ & $\begin{array}{l}159 \\
(11.2)\end{array}$ & $\begin{array}{l}21 \\
(1.5)\end{array}$ & $\begin{array}{l}388 \\
(27.4)\end{array}$ & 0 & $\begin{array}{l}193 \\
(13.6)\end{array}$ & $\begin{array}{l}62 \\
(4.4)\end{array}$ & $8(0.6)$ & $\begin{array}{l}91 \\
(6.4)\end{array}$ & $\begin{array}{l}16 \\
(1.1)\end{array}$ & $\begin{array}{l}15 \\
(1.1)\end{array}$ & $\begin{array}{l}217 \\
(15.3)\end{array}$ & 1415 \\
\hline & Seniors & $\begin{array}{l}78 \\
(6.4)\end{array}$ & $\begin{array}{l}41 \\
(3.3)\end{array}$ & $\begin{array}{l}54 \\
(4.4)\end{array}$ & $\begin{array}{l}31 \\
(2.5)\end{array}$ & $\begin{array}{l}6 \\
(0.5)\end{array}$ & $\begin{array}{l}92 \\
(7.5)\end{array}$ & $\begin{array}{l}12 \\
(9.4)\end{array}$ & $\begin{array}{l}384 \\
(31.3)\end{array}$ & 0 & $\begin{array}{l}135 \\
(11.0)\end{array}$ & $\begin{array}{l}61 \\
(5.0)\end{array}$ & $3(0.3)$ & $\begin{array}{l}91 \\
(7.5)\end{array}$ & $\begin{array}{l}12 \\
(9.4)\end{array}$ & $\begin{array}{l}12 \\
(9.4)\end{array}$ & $\begin{array}{l}214 \\
(17.4)\end{array}$ & 1228 \\
\hline
\end{tabular}




\begin{tabular}{|c|c|c|c|c|c|c|c|c|c|c|c|c|c|c|c|c|c|c|}
\hline Gender & $\begin{array}{l}\text { With female } \\
\text { participants }\end{array}$ & $\begin{array}{l}78 \\
(5.4)\end{array}$ & $\begin{array}{l}43 \\
(3.0)\end{array}$ & $\begin{array}{l}98 \\
(6.7)\end{array}$ & $\begin{array}{l}33 \\
(2.3)\end{array}$ & $\begin{array}{l}12 \\
(0.8)\end{array}$ & $\begin{array}{l}162 \\
(11.1)\end{array}$ & $\begin{array}{l}23 \\
(1.6)\end{array}$ & $\begin{array}{l}390 \\
(26.8)\end{array}$ & $\begin{array}{l}17 \\
(1.2)\end{array}$ & $\begin{array}{l}188 \\
(12.9)\end{array}$ & $\begin{array}{l}62 \\
(4.3)\end{array}$ & $\begin{array}{l}11 \\
(0.8)\end{array}$ & $\begin{array}{l}90 \\
(6.2)\end{array}$ & $\begin{array}{l}17 \\
(1.2)\end{array}$ & $\begin{array}{l}15 \\
(1.0)\end{array}$ & $\begin{array}{l}217 \\
(14.9)\end{array}$ & 1456 \\
\hline & $\begin{array}{l}\text { With male } \\
\text { participant }\end{array}$ & $\begin{array}{l}77 \\
(5.4)\end{array}$ & $\begin{array}{l}43 \\
(3.0)\end{array}$ & $\begin{array}{l}94 \\
(6.6)\end{array}$ & $\begin{array}{l}33 \\
(2.3)\end{array}$ & $\begin{array}{l}13 \\
(0.9)\end{array}$ & $\begin{array}{l}147 \\
(10.2)\end{array}$ & $\begin{array}{l}23 \\
(1.6)\end{array}$ & $\begin{array}{l}389 \\
(27.1)\end{array}$ & $\begin{array}{l}17 \\
(1.2)\end{array}$ & $\begin{array}{l}191 \\
(13.3)\end{array}$ & $\begin{array}{l}61 \\
(4.3)\end{array}$ & $\begin{array}{l}11 \\
(0.8)\end{array}$ & $\begin{array}{l}90 \\
(6.3)\end{array}$ & $\begin{array}{l}16 \\
(1.1)\end{array}$ & $\begin{array}{l}15 \\
(1.0)\end{array}$ & $\begin{array}{l}217 \\
(15.1)\end{array}$ & 1437 \\
\hline
\end{tabular}

Adults $=18-65$ years old; Seniors $=\geq 66$ years old.

*Total No of different studies by “condition". Since many studies included different age groups and genders, the sum of the studies by each age group and gender is greater than the total number of studies.

MIO: Ischaemic heart disease; CBD: Cerebrovascular disease; RTI: Lower respiratory infections; COP: Chronic obstructive pulmonary disease; DIA:

Diarrhoeal diseases; HIV: HIV/AIDS; TBC: Tuberculosis; RTN: Trachea, bronchus, lung cancers; PLW: Prematurity and low birth weight; DBM: Diabetes mellitus; HFA: Heart failure; MAL: Malaria; LVC: Cirrhosis of the liver; N\&N: nephritis and nephrosis; CRC: Colon and rectum cancers 